\title{
Biochemical and Physical Changes in Shaken Suspensions of Pasteurella pestis
}

\author{
G. E. WESSMAN ${ }^{1}$ AND DONNA J. MILLER \\ U.S. Army Biological Laboratories, Fort Detrick, Frederick, Maryland
}

Received for publication 18 March 1966

\begin{abstract}
Wessman, G. E. (Fort Detrick, Frederick, Md.), AND D. J. Miller. Biochemical and physical changes in shaken suspensions of Pasteurella pestis. Appl. Microbiol. 14:636-642. 1966.- Pasteurella pestis, harvested after 24 to $30 \mathrm{hr}$ of growth in a casein hydrolysate medium at $26 \mathrm{C}$, was resuspended and shaken in $3 \%$ lactose$0.1 \mathrm{M}$ phosphate buffer for $4 \mathrm{hr}$ at the same temperature. Certain characteristics of these starved cells were compared with those of control cells. No differences in the amounts of cellular carbohydrate or lipid were detected. The concentrations of the principal free amino acids were greater in the shaken cells, except that they contained no measureable arginine, and the normally large pools of intracellular tricarboxylic acid cycle intermediates were reduced. Greater viable-cell counts resulted with the cells that were shaken in lactose buffer than with the control cells when each was incubated at $5 \mathrm{C}$ for several weeks. However, the reduced viabilities were apparent losses caused by the formation of aggregates of cells. The clumping of cells was caused by the polymerization of extracellular nucleic acids, principally deoxyribonucleic acid, that were excreted by the cells. Cell clumping could be partially prevented by prior shaking of the suspended cells, which removed some of the deleterious material, or by the action of crystalline deoxyribonuclease.
\end{abstract}

The viability of bacterial cells in a culture or suspension is a relative property dependent upon the manner in which that viability is assayed. Whether a cell is considered "alive" or not usually depends upon its ability to multiply in some particular cultural environment designed to measure growth. In this work, apparent reduction of viability of suspensions of Pasteurella pestis during incubation at $5 \mathrm{C}$ resulted primarily from the excretion of nucleic acids from the cells, which caused aggregates of cells, so that the method of enumerating the bacteria did not accurately assess each single cell. Changes in properties of the cells during shaking of suspensions of cells under conditions of starvation are also reported and discussed in terms of their influence upon subsequent incubation of the cells at $5 \mathrm{C}$.

\section{Materials AND Methods}

Bacteriological procedures. The virulent Alexander strain (13) was employed. The maintenance of stock cultures and the growth of organisms for experimentation were conducted as previously described

\footnotetext{
1 Present address: National Animal Disease Laboratory, U.S. Department of Agriculture, Ames, Iowa.
}

(21). The organisms were grown in the de-acidified casein partial hydrolysate medium of Higuchi and Carlin (15).

Cells were separated from the medium by centrifugation and resuspended at one-half the original culture concentration in $3 \%$ lactose- $0.1 \mathrm{M}$ potassium phosphate buffer, $p H$ 7.4 (lactose buffer). Samples $(10 \mathrm{ml})$ of the suspension were then placed in 18-ml serum bottles (fitted with rubber stoppers) for continued incubation at $5 \mathrm{C}$. Some suspensions were shaken for periods up to $4 \mathrm{hr}$ before incubating them at $5 \mathrm{C}$. This was done by placing $50 \mathrm{ml}$ of suspended cells in a 500-ml Erlenmeyer flask and shaking on a reciprocating shaker (100 excursions per min) at 26 C. All experiments were conducted with duplicate samples. Routine methods for sampling and counting were those reported by Mead et al. (21).

Virulence was determined by intraperitoneal challenge of mice as outlined by Fukui et al. (13).

Biochemical methods. Protein determinations were made by the biuret method described by Stickland (25), or by the Folin phenol method of Lowry et al. (20). Carbohydrate, after precipitation with alcohol, was measured by the anthrone method outlined by Gary et al. (14). Lipid was determined by a modification of the method of Kibrick and Skupp (18). Total nucleic acids were measured in a Beckman model DU spectrophotometer at $260-\mathrm{m} \mu$ wavelength after treating cells with $5 \%$ trichloroacetic acid and 
diluting with $0.01 \mathrm{~N} \mathrm{NaOH}$. Total nitrogen was determined by the method of Johnson (16).

Intracellular pools of free amino acids and tricarboxylic acid cycle intermediates were assayed after extracting the cells with hot $(100 \mathrm{C})$ water. Chromatographic determinations for amino acids were made by the method of Levy and Chung (19). Quantitative measurements were made by spectrophotometric readings on acetone eluates of the ninhydrin colored spots. The tricarboxylic acid cycle compounds were extracted for $48 \mathrm{hr}$ with ether and chromatographed according to Denison and Phares (11).

Conventional Warburg techniques were used for quantitative respiration studies.

Enzyme preparations were dissolved in $0.85 \%$ $\mathrm{NaCl}$ and sterilized by filtration through an ultrafine sintered-glass filter.

\section{RESULTS}

Cells, suspended and shaken in lactose buffer after separation from the culture medium, were compared with untreated control cells. Numbers of viable cells did not change during shaking, nor was there any detectable change in intraperitoneal virulence for mice. However, certain characteristics of the shaken suspensions were altered. When the cells were resuspended in lactose buffer and incubated for several weeks at $5 \mathrm{C}$, higher viable counts were obtained than from the control cells (Table 1).

Other suspending fluids were inferior to lactose buffer in improving viability. They included lactose buffer plus salts of various organic acids, lactose buffer plus xylose or glucose, phosphate or tris-(hydroxymethyl)aminomethane (Tris) buffers, $0.85 \% \mathrm{NaCl}$, and distilled water. The temperature during shaking $(5,26$, or $37 \mathrm{C})$ was not critical, although numbers of cells decreased slightly after $4 \mathrm{hr}$ at $37 \mathrm{C}$. The $p \mathrm{H}$ of the suspending fluid exerted only a slight effect, with a permissible range of 6.0 to 7.8 , and an optimum of 7.0 to 7.4 .
Attempts were made to relate increased viability of cells incubated at $5 \mathrm{C}$ to cellular changes occurring during the shaking period. Modification of metabolism at $5 \mathrm{C}$ may have depended upon changes in cellular reserve materials; depletion of reserve carbohydrate during the shaking period might limit production of acidic compounds at $5 \mathrm{C}$. However, $P$. pestis did not accumulate significant amounts of carbohydrate during growth; concentrations ranged from 0.3 to $0.7 \%$ of the dry weight of the cell. Protein and lipid percentages were 68 to 77 and 6.3 to 8.0 , respectively. These concentrations did not change during the shaking period.

A decrease in the rate of endogenous respiration, however, indicated changes in cellular composition. Two distinct rates of oxygen consumption were noted when freshly harvested cells were tested (Table 2). The initial rate was maintained for 1 to $2 \mathrm{hr}$, followed by a reduced rate, which persisted for $72 \mathrm{hr}$ or longer. This suggested the exhaustion of a primary substrate and the secondary attack on another substance. The uptake of oxygen by cells first shaken in lactose buffer occurred only at the lower rate. Cells, incubated for 8 weeks at $5 \mathrm{C}$, possessed relatively high rates of endogenous respiration, with little difference between control and shaken cells. This indicated that metabolically active material accumulated during the incubation at 5 C. Similar results were obtained with cells incubated for 4 weeks.

Assays were made to determine the primary material metabolized during the shaking period. Examination of cellular free amino acid pools revealed increased concentrations of glutamic and aspartic acids and of lysine, but arginine disappeared (Table 3). Trace amounts of alanine, tyrosine, methionine, leucine, isoleucine, valine, and histidine were noted, but were not quantita-

TABLE 1. Effect of shaking suspensions of Pasteurella pestis at 26 upon subsequent viability at $5 \mathrm{C}$

\begin{tabular}{|c|c|c|c|c|}
\hline \multirow{2}{*}{ Shaken in } & \multirow{2}{*}{ Resuspended in } & \multirow{2}{*}{$\begin{array}{c}\text { Initial via- } \\
\text { ble-cell count } \\
\left(X / 10^{8} \mathrm{ml}\right)\end{array}$} & \multicolumn{2}{|c|}{$\begin{array}{l}\text { Per cent of } \\
\text { initial count }\end{array}$} \\
\hline & & & $\begin{array}{c}4 \\
\text { weeks }\end{array}$ & $\begin{array}{c}8 \\
\text { weeks }\end{array}$ \\
\hline Lactose buffer & Fresh lactose buffer & 192 & 89 & 67 \\
\hline Lactose buffer & Supernatant fluid after shaking $4 \mathrm{hr}$ & 176 & 81 & 41 \\
\hline Lactose buffer & $\begin{array}{l}\text { Heated supernatant fluid after shak- } \\
\text { ing for } 4 \mathrm{hr}^{a}\end{array}$ & 169 & 85 & 45 \\
\hline Lactose buffer & Not resuspended & 206 & 71 & 40 \\
\hline $\mathrm{NaCl}, 0.85 \%$ & Fresh lactose buffer & 205 & 73 & 61 \\
\hline $\begin{array}{l}\text { Control (suspended in lactose buffer, } \\
\text { not shaken) }\end{array}$ & & 212 & 59 & 30 \\
\hline
\end{tabular}

\footnotetext{
${ }^{a}$ Heated at $100 \mathrm{C}$ for $2 \mathrm{~min}$.
} 
TABLE 2. Endogenous respiration of Pasteurellu pestis ${ }^{a}$

\begin{tabular}{|c|c|c|}
\hline \multirow{2}{*}{ Prepn } & \multicolumn{2}{|c|}{$\mathrm{Q}_{\mathrm{O}_{2}}(\mathrm{~N})$} \\
\hline & $\begin{array}{c}0-90 \\
\text { min }\end{array}$ & $\begin{array}{l}90-180 \\
\min \end{array}$ \\
\hline Freshly harvested cells & & \\
\hline Control cells . . . . . . & 51 & 29 \\
\hline Cells shaken $4 \mathrm{hr} \ldots \ldots \ldots$ & 28 & 28 \\
\hline Cells incubated at $5 \mathrm{C}, 8$ weeks & & \\
\hline Control cells $\ldots \ldots \ldots \ldots \ldots$ & 52 & 51 \\
\hline Cells shaken $4 \mathrm{hr} \ldots \ldots$ & 48 & 47 \\
\hline
\end{tabular}

${ }^{a}$ Each respirometer flask contained $1.0 \mathrm{ml}$ of $0.1 \mathrm{M}$ phosphate buffer $(p \mathrm{H} 7.4), 1 \mathrm{ml}$ of suspension of washed cells containing 1.5 to $2.0 \mathrm{mg}$ of nitrogen, $0.2 \mathrm{ml}$ of $20 \% \mathrm{KOH}$ in center well, and distilled water to volume $(3.2 \mathrm{ml})$. Temperature, $28 \mathrm{C}$.

TABLE 3. Changes in concentrations of free amino acids of Pasteurella pestis during shaking of suspensions at $26 C$

\begin{tabular}{|c|c|c|}
\hline \multirow{2}{*}{ Amino acid } & \multicolumn{2}{|c|}{$\operatorname{Concn}^{a}$} \\
\hline & $\begin{array}{l}\text { Before } \\
\text { shaking }\end{array}$ & $\begin{array}{l}\text { After } \\
\text { shaking }\end{array}$ \\
\hline Aspartic acid. & 22 & 32 \\
\hline Arginine $\ldots . .$. & 32 & 0 \\
\hline Glutamic acid. . & 51 & 90 \\
\hline Lysine $\ldots \ldots \ldots \ldots$ & 43 & 64 \\
\hline
\end{tabular}

${ }^{a}$ Micrograms of amino acid per milligram of cellular nitrogen.

tively determined. The direct contribution of free amino acid pools to endogenous respiration was minor.

The principal metabolites attacked during the period of rapid endogenous respiration appeared to be tricarboxylic acid cycle compounds, which constitute large intracellular pools in $P$. pestis (23). Qualitative chromatographic examination showed easily identifiable spots of succinic acid and smaller amounts of citric and $\alpha$-ketoglutaric acids. The concentration of succinic acid remaining after shaking the cells in lactose buffer was estimated as approximately one-third its original amount; the citric acid and $\alpha$-ketoglutaric acid spots were no longer detectable.

Significant increases in viability of cells at $5 \mathrm{C}$ were obtained only when cells shaken in lactose buffer were resuspended in fresh lactose buffer (Table 1). Incubation of cells without removal of the shaking menstruum resulted in only slight improvement over the control. This suggested that the lactose buffer in which the cells were shaken contained deleterious substances washed from the cells. This was demonstrated by concentrating the factor(s) and examining the subsequent effect of the concentrates upon viability at $5 \mathrm{C}$. Washed cells were resuspended at various concentrations in lactose buffer and shaken for 4 $\mathrm{hr}$. The cells were separated and the supernatant fluids (theoretically containing various amounts of the factors) were used to suspend another preparation of cells, which was then reincubated in the usual manner. Table 4 shows that an increase in the concentration of the materials washed from the cells resulted in reduction of the viable counts at 8 weeks.

In preliminary studies to identify the materials removed from the cells, accumulation of protein and nucleic acids in the supernatant fluid during the shaking period was measured. A portion of a suspension of 24 -hr-old cells in $0.85 \% \mathrm{NaCl}$ was washed by centrifugation. A second sample was shaken for $4 \mathrm{hr}$ at $26 \mathrm{C}$, and a third was first washed by centrifugation, resuspended, and then shaken. The concentration of cells was increased to four times that normally used in order to obtain quantitatively measurable amounts of material. Analyses of the washing fluid showed about six times as much protein as nucleic acid, both of which were apparently loosely attached to the cells (Table 5). The more firmly bound material, represented by that removed only after $4 \mathrm{hr}$ of shaking, contained a much higher ratio of nucleic acid to protein, and exceeded the normal ratio (approximately 1:4) for the cellular composition of $\boldsymbol{P}$. pestis.

Limited evidence was obtained that these

TABLE 4. Effect of concentration of materials washed from Pasteurella pestis upon viability at $5 \mathrm{C}$

\begin{tabular}{|c|c|c|c|}
\hline \multirow{2}{*}{ Resuspended in } & \multirow{2}{*}{$\begin{array}{c}\text { Initial } \\
\text { viable-cell } \\
\text { count } \\
\left(\times 10^{8} / \mathrm{ml}\right)\end{array}$} & \multicolumn{2}{|c|}{$\begin{array}{l}\text { Per cent } \\
\text { of initial } \\
\text { count }\end{array}$} \\
\hline & & 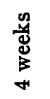 & $\begin{array}{l}\infty \\
\stackrel{\infty}{*} \\
\infty \\
\infty \\
\infty\end{array}$ \\
\hline Fresh lactose buffer ......... & 226 & 69 & 63 \\
\hline $\begin{array}{l}\text { Supernatant fluid after } 4 \mathrm{hr} \text { of } \\
\text { shaking } \ldots \ldots \ldots \ldots \ldots \ldots \ldots\end{array}$ & 221 & 69 & 40 \\
\hline $\begin{array}{l}\text { Supernatant fluid after } 4 \mathrm{hr} \text { of } \\
\text { shaking, } 2 \times \text { concentrated. }\end{array}$ & 211 & 69 & 38 \\
\hline $\begin{array}{l}\text { Supernatant fluid after } 4 \mathrm{hr} \text { of } \\
\text { shaking, } 3 \times \text { concentrated. }\end{array}$ & 248 & 67 & 31 \\
\hline $\begin{array}{l}\text { Supernatant fluid after } 4 \mathrm{hr} \text { of } \\
\text { shaking, } 4 \times \text { concentrated. }\end{array}$ & 238 & 64 & 27 \\
\hline $\begin{array}{c}\text { Control, lactose buffer, not } \\
\text { shaken } \ldots \ldots \ldots \ldots \ldots \ldots\end{array}$ & 171 & 63 & 47 \\
\hline
\end{tabular}


TABLE 5. Protein and nucleic acid content of supernatant fluids of suspensions of Pasteurella pestis

\begin{tabular}{|c|c|c|c|}
\hline \multirow{2}{*}{ Cell treatment } & \multicolumn{3}{|c|}{ Analysis of supernatant fluid } \\
\hline & Protein & Nucleic acid & $\begin{array}{c}\text { Nucleic acid/ } \\
\text { protein }\end{array}$ \\
\hline \multirow{4}{*}{$\begin{array}{l}\text { Washed in } 0.85 \% \mathrm{NaCl} \ldots \ldots \ldots \ldots \ldots \ldots \ldots \ldots \ldots \\
\text { Shaken at } 26 \mathrm{C}, 4 \mathrm{hr} \text { in } 0.85 \% \mathrm{NaCl} \text {; no prior washing. } \\
\text { Shaken at } 26 \mathrm{C}, 4 \mathrm{hr} \text { in } 0.85 \% \mathrm{NaCl} \text { after washing by sus- } \\
\text { pension and centrifugation in } 0.85 \% \mathrm{NaCl} \ldots \ldots \ldots \ldots . .\end{array}$} & $\mu g / m l$ & $\mu \mathrm{g} / \mathrm{ml}$ & \\
\hline & 733 & 125 & $1 / 5.9$ \\
\hline & 940 & 240 & $1 / 3.9$ \\
\hline & 217 & 87 & $1 / 2.5$ \\
\hline
\end{tabular}

TABLE 6. Effect of enzymes during shaking of suspensions of Pasteurella pestis at $26 C$ upon subsequent viability at $5 C$

\begin{tabular}{|c|c|c|c|}
\hline Pretreatment condition & Enzyme prepn ${ }^{a}$ & $\begin{array}{l}\text { Initial viable-cell } \\
\text { count }\left(\times 10^{8} / \mathrm{ml}\right)\end{array}$ & $\begin{array}{l}\text { Per cent of initial } \\
\text { count at } 8 \text { weeks }\end{array}$ \\
\hline Static, $4 \mathrm{hr}$ & $\begin{array}{l}0.1 \% \text { pancreatin } \\
0.1 \% \text { trypsin } \\
0.1 \% \text { ribonuclease } \\
0.002 \% \text { ribonuclease } \\
0.002 \% \text { deoxyribonuclease } \\
\text { None }\end{array}$ & $\begin{array}{l}92.5 \\
75.4 \\
89.4 \\
85.4 \\
85.5 \\
91.2\end{array}$ & $\begin{array}{l}53 \\
51 \\
54 \\
62 \\
74 \\
50\end{array}$ \\
\hline Shaken $4 \mathrm{hr}$ & $\begin{array}{l}0.1 \% \text { pancreatin } \\
0.1 \% \text { trypsin } \\
0.1 \% \text { ribonuclease } \\
0.002 \% \text { ribonuclease } \\
0.002 \% \text { deoxyribonuclease } \\
\text { None }\end{array}$ & $\begin{array}{l}86.2 \\
74.5 \\
88.5 \\
85.2 \\
87.8 \\
92.7\end{array}$ & $\begin{array}{l}63 \\
69 \\
55 \\
69 \\
86 \\
64\end{array}$ \\
\hline Control (no pretreatment) & & 97.9 & 40 \\
\hline
\end{tabular}

${ }^{a}$ Enzymes dissolved in $0.85 \% \mathrm{NaCl}$ and sterilized by passage through an ultrafine sintered-glass filter. All suspensions received 0.15 mmole of $\mathrm{MgSO}_{4}$.

TABLE 7. Effect of dispersion of aggregated cells upon viability of shaken and control suspensions of Pasteurella pestis

\begin{tabular}{|c|c|c|c|c|}
\hline \multirow{2}{*}{ Cell suspension } & \multirow{2}{*}{$\begin{array}{l}\text { Counting } \\
\text { technique }\end{array}$} & \multirow{2}{*}{$\begin{array}{c}\text { Initial } \\
\text { viable-cell } \\
\text { count } \\
\left(\times 10^{8} / \mathrm{ml}\right)\end{array}$} & \multicolumn{2}{|c|}{$\begin{array}{l}\text { Per cent of } \\
\text { initial count }\end{array}$} \\
\hline & & & $\begin{array}{c}4 \\
\text { weeks }\end{array}$ & $\begin{array}{c}8 \\
\text { weeks }\end{array}$ \\
\hline \multirow{2}{*}{$\begin{array}{l}\text { Shaken at } \\
26 \mathrm{C}, 4 \mathrm{hr}\end{array}$} & Routine & 193 & 78 & 50 \\
\hline & Kahn-shaken & 195 & 84 & 56 \\
\hline \multirow[t]{2}{*}{ Control } & Routine & 202 & 51 & 23 \\
\hline & Kahn-shaken & 204 & 78 & 39 \\
\hline
\end{tabular}

extracellular nucleic acids or nucleoproteins may cause the apparent reduction of cell viability by creating aggregates of cells. Experiments in which enzymes were added to cell suspensions at the beginning of the shaking period suggested that polymers of nucleic acids, particularly deoxyribonucleic acid (DNA), may be responsible.
Suspensions of cells were treated with predetermined concentrations of four enzymatic preparations. Viable counts increased after the addition of deoxyribonuclease (Table 6). The effect of ribonuclease was less definite. Trypsin caused a considerable reduction in cell numbers during the shaking period.

The data suggested that reduced viable-cell counts resulted from aggregation of cells rather than death. Confirmation of this was obtained in the following experiment. A culture was separated into two samples, centrifuged, and suspended in lactose buffer. One sample was incubated at $5 \mathrm{C}$ without shaking; one was shaken for $4 \mathrm{hr}$ at $26 \mathrm{C}$, resuspended in lactose buffer, and incubated at $5 \mathrm{C}$. In addition to the routine cell counts, viability was also determined after subjecting the samples to rigorous agitation to disintegrate clumps of cells. This was done by fixing the serum bottle horizontally on a Kahn shaker for $1 \mathrm{hr}$ of shaking at 300 excursions per min. Table 7 shows that the difference between 
counts of Kahn-shaken cells and routine counts was much smaller for cell suspensions first shaken for $4 \mathrm{hr}$ than for the controls. Since the two differed because of clumping of cells, it seems valid to assume that viability was increased at $5 \mathrm{C}$ because the shaking process at $26 \mathrm{C}$ removed materials that caused clumping.

\section{Discussion}

Intracellular changes during shaking of suspensions of $P$. pestis at $26 \mathrm{C}$ probably affect subsequent behavior at $5 \mathrm{C}$, but clumping of cells by extracellular DNA accounts for most of the apparent reduction in viability. Polymerized DNA causes clumping in cultures of other microorganisms. Smithies and Gibbons (24) found that the DNA-containing slime layer of various halophiles could be dispersed with crystalline deoxyribonuclease. Catlin $(4,5)$ identified polymerized DNA as the main component of slimes from species of Micrococcus, Alcaligenes, Pseudomonas, and Neisseria. Jones (17) showed that ropiness of milk, due to Aerobacter aerogenes, was associated with extracellular nucleoprotein. Two experimental results indicate a similar cause for aggregation of $\boldsymbol{P}$. pestis at $5 \mathrm{C}$. The ratio of nucleic acid to protein in the suspending fluid after shaking at $26 \mathrm{C}$ indicates a high concentration of extracellular nucleic acids. Increased viable counts of suspensions at $5 \mathrm{C}$ treated with crystalline deoxyribonuclease during shaking implies the dispersion of polymerized DNA, reducing subsequent clumping of cells.

Extracellular DNA originates from DNA formed inside the cell and then excreted. Although it has been generally conceded that excretion of DNA results from cell rupture $(5,27)$, it is now suggested that DNA may pass the cell barriers without concomitant lysis of the cell. Ottolenghi and Hotchkiss (22) and Demain, Burg, and Hendlin (10) demonstrated the accumulation of extracellular DNA in the absence of visible lysis. Campbell et al. (2) indicated that cellular lysis may not be necessary, by demonstrating that transfer of cells in the act of excretion from the growth medium to distilled water stopped excretion. In our work, accumulation of extracellular DNA was not accompanied by visible lysis.

Excretion of DNA into the cultural medium has been related to nutritional stress such as that in aging cultures (5; Catlin, Bacteriol. Proc., p. 123, 1956). The activity of extracellular deoxyribonucleases generally prevents accumulation of DNA slime, but the presence of the enzyme may depend upon nutritional conditions. An enzyme produced by $M$. pyogenes var. aureus required calcium ions and high $p \mathrm{H}$ for activity; in the absence of these conditions, DNA slime accumulated (6). The composition of the medium also influences the accumulation of extracellular DNA by other species, i.e., M. halodenitrificans (27), Brucella sp. (Mauzy, Braun, and Whallon, Bacteriol. Proc., p. 46, 1955), and M. sodonensis (2). However, Ottolenghi and Hotchkiss (22) indicated that nutritional imbalance is not necessary because young pneumococcal cultures accumulate extracellular DNA under optimal growth conditions. The cultures of $P$. pestis in our studies consisted of logarithmic and stationary-phase cells grown under adequate nutritional conditions, and the influence of cultural factors is undetermined. Cultures growing at $26 \mathrm{C}$ frequently, however, do form aggregates of cells that adhere to the sides of the flask; possibly, extracellular DNA is a primary cause of this phenomenon. Perhaps lysis of a portion of the cells results from changes in the cultural medium. $P$. pestis lyses readily under certain environmental conditions $(1,28)$.

The cell suspensions were shaken originally in lactose buffer for several hours at $26 \mathrm{C}$ to reduce reserve compounds that might be catabolized during subsequent incubation at $5 \mathrm{C}$. Depletion of some material(s) during starvation at $26 \mathrm{C}$ is reflected in the data on endogenous respiration. The two distinct rates of oxygen uptake by freshly harvested cells suggest attacks on different unidentified types of substrate. Carbohydrate and lipid concentrations remained constant during the 4-hr shaking period, indicating that these were not the early sources of endogenous substrate. Concentrations of poly$\beta$-hydroxybutyrate, an important reserve material in many bacteria (9), were not measured, however. Free amino acid pools often serve as substrates for endogenous metabolism, as first shown by Dawes and Holms (7). In our work, the concentrations of three of four principal free amino acids increased during starvation, instead of diminishing. However, the relatively large intracellular pools of tricarboxylic acid cycle compounds, particularly succinic acid, probably contributed significantly to the early rapid rate of oxygen uptake.

The slower, secondary rate of endogenous respiration, which continued for more than $\mathbf{7 2}$ $\mathrm{hr}$, probably was due to oxidation of protein or lipid. Strange, Dark, and Ness (26) first demonstrated the utilization of protein as an endogenous substrate for Aerobacter aerogenes; data by other workers suggest that this is a general phenomenon among microorganisms (9). The 
utilization of lipid as substrate for endogenous metabolism, especially as a secondary substrate, was discussed by Dawes and Ribbons (8). The death of a small number of cells during a long respirometer experiment, with the accompanying release of oxidizable material, might also have contributed to endogenous metabolism.

The increased rate of endogenous respiration of cells after 4 or 8 weeks of incubation at $5 \mathrm{C}$ is similar to the findings of Campbell, Gronlund, and Duncan (3) with Pseudomonas aeruginosa. Cells, first aerated to reduce endogenous respiration, had increased respiration rates after being held in buffer for 6 days at 0 C. Pasteurella pestis, which grows and metabolizes fairly well at $5 \mathrm{C}$ (12), may accumulate readily oxidizable compounds at this temperature, even in the absence of utilizable exogenous substrate; these might come from normal cell or reserve constituents. Lactose in the suspending fluid is not metabolized, because no change in concentration can be detected. Dying cells may be scavenged by their neighbors, causing the accumulation of oxidizable reserve materials. Under the conditions employed in these studies, moderate quantities of acidic compounds accumulate. Suspensions often reach $p \mathrm{H}$ levels of less than 6.5 (21), indicating some kind of biochemical activity. Even if the cells are not growing or dying, energy must be expended to enable them to maintain their integrity. The significance of endogenous metabolism of $P$. pestis in relation to continued viability in suspensions at $5 \mathrm{C}$ has not been established, however, by our data.

\section{ACKNOWLEDGMENTS}

We express our appreciation to N. D. Gary, M. J. Surgalla, and L. H. Graf for their suggestions and criticism in the preparation of the manuscript, and we acknowledge the capable technical assistance of Hyder L. Johnson.

\section{Literature Cited}

1. Brubaker, R. R., and M. J. Surgalla. 1964. The effect of $\mathrm{Ca}^{++}$and $\mathrm{Mg}^{++}$on lysis, growth, and production of virulence antigens by Pasteurella pestis. J. Infect. Diseases 114:13-25.

2. Campbell, J. N., J. B. Evans, J. J. Perry, and C. F. Niven, JR. 1961. An extracellular material elaborated by Micrococcus sodonensis. J. Bacteriol. 82:828-837.

3. Campbell, J. J. R., A. F. Gronlund, AND M. G. DunCAN. 1963. Endogenous metabolism of Pseudomonas. Ann. N.Y. Acad. Sci. 102:669677.

4. Catlin, B. W. 1956. Extracellular deoxyribonucleic acid of bacteria and a deoxyribonuclease inhibitor. Science 124:441-442.

5. Catlin, B. W. 1960 . Interspecific transformation of Neisseria by culture slime containing deoxyribonucleate. Science 131:608-610.

6. Catlin, B. W., and L. S. Cunningham. 1958 Studies of extracellular and intracellular bacterial deoxyribonucleate acids. J. Gen. Microbiol. 19:522-539.

7. Dawes, E. A., AND W. W. Holms. 1958. Metabolism of Sarcina lutea. III. Endogenous metabolism. Biochim. Biophys. Acta 30:278-293.

8. Dawes, E. A., AND D. W. Ribbons. 1962. The endogenous metabolism of microorganisms. Ann. Rev. Microbiol. 16:241-264.

9. DAWEs, E. A., AND D. W. Ribbons. 1964. Some aspects of the endogenous metabolism of bacteria. Bacteriol. Rev. 28:126-149.

10. Demain, A. L., R. W. BuRg, ANd D. Hendlin. 1965. Excretion and degradation of ribonucleic acid by Bacillus subtilis. J. Bacteriol. 89:640 646.

11. Denison, F. W., Jr., and E. F. Phares. 1952. Rapid method for paper chromatography of organic acids. Anal. Chem. 24:1628-1629.

12. Fukui, G. M., W. D. Lawton, D. A. HaM, W. A. Janssen, And M. J. Surgalla. 1960. The effect of temperature on the synthesis of virulence factors by Pasteurella pestis. Ann. N.Y. Acad. Sci. 88:1146-1151.

13. Fukul, G. M., J. E. OgG, G. E. Wessman, and M. J. Surgalla. 1957. Studies on the relation of cultural conditions and virulence of Pasteurella pestis. J. Bacteriol. 74:714-717.

14. Gary, N. D., L. L. Kupferberg, R. E. ANDERSON, P. K. Harein, and R. E. Klausmeier. 1957. Nutritional factors influencing the polysaccharide production of Brucella suis. J. Bacteriol. 73:632-640.

15. Higuchi, K., and C. E. Carlin. 1957. Studies on the nutrition and physiology of Pasteurella pestis. I. A casein hydrolyzate medium for the growth of Pasteurella pestis. J. Bacteriol. 73:122-129.

16. Johnson, M. J. 1941. Isolation and properties of a pure yeast polypeptidase. J. Biol. Chem. 137:375-376.

17. JONES, D. L. 1954. Ropy milk. III. Chemical studies of a ropy substance. Food Res. 19: 254-256.

18. Kibrick, A. C., AND S. J. Skupp. 1953. Colorimetric method for the determination of fatty acids in blood by oxidation with dichromate. Arch. Biochem. Biophys. 44:134-139.

19. Levy, A. L., AND D. Churis. 1953. Two-dimensional chromatography of amino acids on buffered papers. Anal. Chem. 25:396-399.

20. Lowry, O. H., N. J. Rosebrough, A. L. Farr, AND R. J. RANDALl. 1951. Protein measurement with the Folin phenol reagent. J. Biol. Chem. 193:265-275.

21. Mead, D. D., G. E. Wessman, K. Higuchi, and M. J. Surgalla. 1960. Stability of cell suspensions of Pasteurella pestis at $5 \mathrm{C}$ and at -23 C. Appl. Microbiol. 8:55-60.

22. Ottolenghi, E., AND R. D. Hotchkiss. 1962. Release of genetic transforming agent from 
pneumococcal cultures during growth and disintegration. J. Exptl. Med. 116:491-519.

23. Santer, M., AND S. AJl. 1954. Metabolic reactions of Pasteurella pestis. I. Terminal oxidation. J. Bacteriol. 67:379-386.

24. Smithies, W. R., AND N. E. Gibbons. 1955. The deoxyribose nucleic acid slime layer of some halophilic bacteria. Can. J. Microbiol. 1:614621.

25. Stickland, L. H. 1951. The determination of small quantities of bacteria by means of the biuret reaction. J. Gen. Microbiol. 5:698-703.
26. Strange, R. E., F. A. Dark, and A. G. Ness. 1961. The survival of stationary phase Aerobacter aerogenes stored in aqueous suspensions. J. Gen. Microbiol. 25:61-76.

27. Takahashi, I., AND N. E. Gibbons. 1957. Effect of salt concentration on the extracellular nucleic acids of Micrococcus halodenitrificans. Can. J. Microbiol. 3:687-694.

28. Wessman, G. E., D. J. Miller, and M. J. SurGALLA. 1958. Toxic effect of glucose on virulent Pasteurella pestis in chemically defined media. J. Bacteriol. 76:368-375. 